\title{
EFFECT OF PHOSPHATE FERTILIZER AND ARBUSCULAR MYCORRHIZAL FUNGI ON THE NUTRIENT CONTENT, PHOSPHATE UPTAKE AND IN VITRO DIGESTIBILITY OF ALFALFA
}

\section{PENGARUH FOSFAT DAN CENDAWAN MIKORIZA ARBUSKULA TERHADAP KANDUNGAN NUTRIEN, SERAPAN P DAN KECERNAAN IN VITRO PADA TANAMAN ALFALFA}

\author{
Bambang Suwignyo ${ }^{1 *}$, Bela Putra ${ }^{1}$, Nafiatul Umami ${ }^{1}$, Cahyo Wulandari ${ }^{2}$, and Ristianto \\ Utomo ${ }^{1}$ \\ ${ }^{1}$ Faculty of Animal Science, Universitas Gadjah Mada, Yogyakarta, 55281 \\ ${ }^{2}$ Faculty of Agriculture, Universitas Gadjah Mada, Yogyakarta, 55281
}

Submitted: 25 July 2016, Accepted: 4 October 2016

\begin{abstract}
This study was aimed to determine the effect of arbuscular mycorrhizal fungi (AMF) and phosphate (P) fertilizer on the nutrient content, phosphate uptake and in vitro digestibility of alfalfa (Medicago sativa L.). The research was conducted at the green house. The experiment was arranged in Completely Randomized Design using $3 \times 4$ factorial patterns with four replications. The first factor was the dosage of phosphate fertilizer SP $36(0,60$, and $120 \mathrm{~kg} / \mathrm{ha})$. Second factor was the dosage of AMF $(0,0.8,1.6$, and $2.4 \mathrm{~kg} / \mathrm{ha}$ ). The variable measured was nutrient contents (crude protein, dry matter, and organic matter), total $\mathrm{P}$ uptake and dry matter and organic matter in vitro digestibility. The results showed that the interaction of $A M F$ and $P$ fertilizer had no significant effect on crude protein content and total $P$ uptake, but highly significant effect organic matter content as well as dry matter and organic matter in vitro digestibility.
\end{abstract}

(Key words: Alfalfa, AMF, Phosphate, Productivity, Regosol soil)

\section{INTISARI}

Penelitian ini bertujuan untuk mengetahui pengaruh cendawan mikoriza arbuskula dan pupuk fosfat terhadap pertumbuhan dan produktivitas alfalfa. Penelitian ini dilaksanakan di rumah kaca Laboratorium Hijauan Makanan Ternak dan Pastura Universitas Gadjah Mada. Penelitian menggunakan Rancangan Acak Lengkap pola faktorial 3 x 4 dengan 4 ulangan. Faktor pertama terdiri dari 3 taraf pemberian pupuk fosfat (SP 36) : 0, 60, dan $120 \mathrm{~kg} / \mathrm{ha}$ dan faktor kedua adalah penambahan cendawan mikoriza arbuskula (CMA) terdiri dari 4 taraf 0, 0,8, 1,6, dan 2,4 kg/ha. Variabel yang diamati berupa analisis tanah, tinggi tanaman, panjang batang, jumlah daun, jumlah tunas, panjang akar, volume akar, berat segar tajuk, berat segar akar, berat kering tanaman, analisis proksimat (protein kasar, bahan kering, bahan organik) serapan $P$ total dan uji kecernaan secara in vitro. Hasil penelitian ini menunjukkan bahwa interaksi CMA dan pupuk SP 36 memberikan pengaruh sangat nyata pada kandungan bahan kering dan bahan organik serta kecernaan.

(Kata kunci: Alfalfa, CMA, Pertumbuhan, Produktivitas, Tanah regosol)

\footnotetext{
* Korespondensi (corresponding author):

Telp. +62 85868967995

E-mail: bsuwignyo@ugm.ac.id
} 


\section{Introduction}

Forage either grass or legume is the main feed for ruminants. Alfalfa (Medicago sativa L.) that has spread throughout the world is one type of legume that is potential as livestock feed for nutritional value and high digestibility. Parman and Harnina (2008) stated that the protein content and chlorophyll of alfalfa is high, which amounted to four times compared with similar plants.

Development of alfalfa requires a good soil. Indonesia has a very wide regosol (psamment) land area that is very potential for alfalfa plant development. The limiting factor in crop production alfalfa regosol soil is the nutrient content of $\mathrm{P}$ (phosphorus), and $\mathrm{K}$ (potassium) is still in the form of rock weathering has not experienced that yet ready to be absorbed by plant roots, soil is also a lack of nitrogen.

Utilization of AMF is one alternative to improve the efficiency of fertilizer and soil improvement efforts regosol. Arbuscular mycorrhizal fungi not only has the potential to improve the uptake of nutrients by the plants, but also has the role of fixing the soil aggregates (Leifheit et al., 2013), as well as reduce the level of plant stress caused by biotic and abiotic factors (Garrido et al., 2010), increasing organic matter in soil (Daynes et al., 2013)

\section{Materials and Methods}

\section{Materials}

Equipment was used in this experimental activities include roller meter, machetes, hoes, containers, plastic, buckets, a set of tools for proximate analysis (dry matter, organic matter and crude protein) and a set of equipment for the analysis of in vitro digestibility.

The materials were used such as regosol soil (was analyzed to determine the nutrient content of $\mathrm{N}, \mathrm{P}$, and $\mathrm{K}$ ), AMF inoculants was taken in the Mycology Laboratory Faculty of Agriculture UGM, label paper, tissue rolls, polybag, urea, $\mathrm{KCl}$, phosphates (SP36), $\mathrm{CO}_{2}, \mathrm{Mc}$ Dougle solution, pepsin $5 \%, \mathrm{HCl} 20 \%$ and alfalfa plant seeds. SP36 was given based on treatment. The $\mathrm{KCl}$ and $\mathrm{N}$ fertilizer were given $100 \mathrm{~kg} / \mathrm{ha}$ and $80 \mathrm{~kg} / \mathrm{ha}$, respectively.

\section{Methods}

The design of this study was Completely Randomized Design factorial pattern of $3 \times 4$ with two treatment factors and four replications. The first factor was the addition of phosphate fertilizers (SP36), which consisted of three levels $(0,60$, and $120 \mathrm{~kg} / \mathrm{ha})$ and four levels AMF offered (0, $0.8,1.6$, and $2.4 \mathrm{~kg} / \mathrm{ha}$ ).

Preparation of planting medium. The soil was randomly taken from selected regosol areas. Soil released from pieces of wood or roots by filtering it through a sieve perforated $2.0 \mathrm{~cm}$. Polybag was randomly arranged and set the appropriate layout research plots then placed in the green house as growth medium of alfalfa. Watering was done every day for 10 days before treatment and planting alfalfa.

Planting crops. Alfalfa seeds were planted $1 \mathrm{~cm}$ depth in the soil as much as 5 grains/polybag. Watering was done every day in accordance with the conditions of growing plant medium. Two of good alfalfa plants were selected from each polybag to be maintained until the end of the study.

Variables observed were nutrients content, P uptake, dry matter and organic matter in vitro digestibility. Nutrients content was analyzed proximate according to AOAC (2005), $P$ uptake was computed from $P$ value that analyzed from harvested plant with AAS method. Plant was separated between stem and roots then analyzed the $P$ uptake. Dry matter and organic matter in vitro digestibility were tested with Tilley and Terry (1963) method.

\section{Maintenance}

Maintenance of alfalfa plants was done by watering the plants in the morning or afternoon according to the condition of the growing medium. Weeds and pests control was done every week.

\section{Variables observed}

Proximate analysis. The plant material was dried in an oven at a temperature of $55^{\circ} \mathrm{C}$ until its weight was constant, then grounded with Wiley mill prior to be analyzed. The content of dry matter (DM), organic matter (BO), and crude protein (CP) were analyzed according to AOAC (2005).

Total P uptake of plants. Total $P$ uptake of plants was analyzed after being harvested. Plant stem was cut sections and separated with the root and then analyzed the P uptake. Observation of total P uptake in the header was done by using AAS methods. 
Dry matter and organic matter in vitro digestibility. Dry matter and organic matter digestibility of alfalfa plants were analyzed using in vitro method of Tilley and Terry (1963).

\section{Data analysis}

The data collected was arranged on Completely Randomized Design using $3 \times 4$ factorial pattern with four replications. The first factor was the dosage of phosphate (SP36) fertilizer, the second factor was the dosage of AMF.

\section{Results and Discussion}

The dry matter and organic matter content

Effect of AMF and phosphates to the average of DM and OM content were listed in Table 1 and Table 2. The results of variance analysis showed that the addition of phosphate fertilizers decreased the dry matter of alfalfa. Alfalfa without phosphates was the highest results of average DM compared to other treatments. The addition of $120 \mathrm{~kg} / \mathrm{ha}$ phosphates produced the lowest average DM and OM compared with the other treatments, the presence of excess phosphate could be a bad factor for plants alfalfa. Qin et al. (2015) reported that phosphate fertilization within the specified time would lead the phosphate accumulation which can be a negative impact on AMF colonization and soil microbes. Arbuscular mycorrhizal fungi help the absorption of phosphate needed by the alfalfa plant. Cozzolino et al. (2010) stated that the use of AMF is very effective to increase the uptake of $P$ for the host plant.

The existence of AMF on alfalfa plants, mycorrhizal fungi normally is associated with the bacteria Rhizobium at root section. The plant will be fulfilled nitrogen fixation by Rhizobium free $\mathrm{N}$ and $\mathrm{P}$ are met from the activity of mycorrhizal fungi. Accordance with the opinion Fusconi (2014) stated that the mutually beneficial relationship between Rhizobium with the AMF, particularly in the process of root nodule formation.

Phosphate fertilizer application at the level of $60 \mathrm{~kg} / \mathrm{ha}$ produced organic matter as much as $86.59 \%$. However, after followed by addition of arbuscular mycorrhizal fungi 0.8 $\mathrm{kg} / \mathrm{ha}$, the organic materials content increased highly significant (89.05\%). These results indicated that the role of arbuscular mycorrhizal fungi (AMF) to mobilize the absorption of nutrients from the soil to the plant through the hyphae especially $\mathrm{N}$. Nitrogen was the most element that accumulated in the OM because it was an important element in the microbial cells involved in the OM soil reform process.

Table 1. Average of dry matter content of alfalfa plants

\begin{tabular}{ccccc}
\hline \hline \multirow{2}{*}{ AMF $(\mathrm{kg} / \mathrm{ha})$} & \multicolumn{3}{c}{ Fertilizer $(\mathrm{kg} / \mathrm{ha})$} & \multirow{2}{*}{ Average } \\
\cline { 2 - 4 } & 0 & 60 & 120 & $29.60 \pm 6.44$ \\
\hline 0.0 & $36.28 \pm 4.07$ & $29.08 \pm 8.90$ & $23.51 \pm 6.92$ & $26.55 \pm 0.96$ \\
0.8 & $27.47 \pm 2.86$ & $26.63 \pm 6.14$ & $25.55 \pm 3.53$ & $22.61 \pm 5.37$ \\
1.6 & $28.66 \pm 11.3$ & $18.43 \pm 5.15$ & $20.74 \pm 10.1$ & $24.18 \pm 2.92$ \\
2.4 & $27.40 \pm 5.99$ & $23.43 \pm 3.85$ & $21.70 \pm 0.94$ & \\
Average & $29.95 \pm 4.26^{\mathrm{a}}$ & $24.39 \pm 4.60^{\mathrm{b}}$ & $22.86 \pm 2.11^{\mathrm{b}}$ & \\
\hline a,b & &
\end{tabular}

Table 2. Average of organic matter content of alfalfa plants

\begin{tabular}{ccccc}
\hline \hline \multirow{2}{*}{ AMF $(\mathrm{kg} / \mathrm{ha})$} & 0 & 60 & \multirow{3}{*}{ Average } \\
\cline { 2 - 4 } & $85.78 \pm 3.55$ & $86.59 \pm 1.53$ & $86.21 \pm 1.32$ & $86.19 \pm 0.41$ \\
0.0 & $87.66 \pm 1.28$ & $89.05 \pm 0.43$ & $82.21 \pm 0.52$ & $86.31 \pm 3.62$ \\
0.8 & $86.16 \pm 0.88$ & $88.17 \pm 1.67$ & $85.43 \pm 0.49$ & $86.59 \pm 1.42$ \\
1.6 & $87.81 \pm 0.44$ & $88.72 \pm 0.52$ & $81.72 \pm 0.45$ & $86.08 \pm 3.81$ \\
2.4 & $86.85 \pm 1.03^{\mathrm{a}}$ & $88.13 \pm 1.09^{\mathrm{a}}$ & $83.89 \pm 2.26^{\mathrm{b}}$ & \\
Average & &
\end{tabular}


Table 3. Average of crude protein content of alfalfa plants

\begin{tabular}{ccccc}
\hline \hline \multirow{2}{*}{ AMF $(\mathrm{kg} / \mathrm{ha})$} & \multicolumn{3}{c}{ Fertilizer $(\mathrm{kg} / \mathrm{ha})$} & \multirow{2}{*}{ Average } \\
\cline { 2 - 4 } & 0 & 60 & 120 & $19.94 \pm 0.85$ \\
0.0 & $20.52 \pm 3.57$ & $20.35 \pm 1.07$ & $18.97 \pm 5.42$ & $20.31 \pm 4.15$ \\
0.8 & $16.94 \pm 1.67$ & $19.05 \pm 2.49$ & $24.95 \pm 2.98$ & $19.24 \pm 1.11$ \\
1.6 & $19.96 \pm 1.59$ & $19.80 \pm 3.32$ & $17.96 \pm 2.44$ & $20.18 \pm 0.86$ \\
2.4 & $20.69 \pm 4.44$ & $19.18 \pm 1.06$ & $20.66 \pm 0.36$ & \\
Average & $19.53 \pm 1.75$ & $19.60 \pm 0.60$ & $20.63 \pm 3.08$ & \\
\hline
\end{tabular}

\section{Crude protein content}

Effect of AMF and phosphates to the average of crude protein content can be seen in Table 3. Results of variance analysis showed that $P$ fertilizer and AMF (single factor or interaction) had no significantly effect on the crude protein content of alfalfa plants. The results were consistent with the research before, showed that $P$ fertilizer did not affect the crude protein content in alfalfa plants (Widyati-Slamet et al., 2008), clover crop (Sabia et al., 2015) and the ginger plant (Modupeola et al., 2013). Phosphate fertilizer application (AMF) had no effect on levels of crude protein because protein is being composed by several elements, and nitrogen is the largest element constituent protein (Barzin et al., 2014).

The results of this study showed that all treatments had similar crude protein content. All treatments contain the same protein was likely due to the age of 60 days alfalfa plants have not been able to collect the crude protein. Nitrogen likelihood was utilized for the growth of alfalfa so at the harvest time (60 days), AMF has not been able to demonstrate the effect of differences in protein content. This opinion supported by Baslam et al. (2014) stated that the nutrients would be used by the plant to grow and trigger a secondary metabolic processes. While $\mathrm{N}$ very important for the growth of leaves and stems (Jones and Ljung, 2012) and root growth (Xie et al., 2014).

In this study, total $\mathrm{N}$ content in the growing media was $0.27 \%$. Nitrogen was sufficient for protein synthesis requirement so that the AMF role on the crude protein content was very minor. Setyanti et al. (2013) state that the total $\mathrm{N}$ content in the soil at level $0.215 \%$ was already met the needs of alfalfa plant.

Plants containing Rhizobium meliloti in alfalfa root nodules were able to do $\mathrm{N}_{2}$ fixation from the air so that the protein needs can be satisfied. Setyanti et al. (2013) stated that role of Rhizobium melliloti was not only on N2 fixation but also including the formation of chlorophyll in leaves and crude protein of alfalfa plants. Wahyuni and Kamaliyah (2012) stated that the alfalfa plant contains high protein so that the AMF role was not very visible in the formation of crude protein in alfalfa plants, but leads to increased growth of the plant. Similar results were also reported by Subantoro et al. (2013), that some Rhizobium inoculation had no impact on the chlorophyll content of three varieties of alfalfa (multiking 1 , vernal and common).

Provision of phosphate as much as $120 \mathrm{~kg} / \mathrm{ha}$ followed by the addition of AMF as much $0,8 \mathrm{~kg} / \mathrm{ha}$ yield the highest crude protein content $(24.95 \%)$, although in statistical tests showed the effect was not significant. Results of this study were higher than the crude protein content of research done by Subantoro et al. (2013) on alfalfa plants without the addition of phosphate treatment and AMF (19.94\%), Sirait et al. (2010) on alfalfa crops without any additional treatment AMF (16.02\%). Arbuscular mycorrhizal fungi help the roots of plants to absorb soil nutrients needed by plants as a protein synthesis. It can explain that the process of transfer of inorganic $\mathrm{N}$ (NO3- and $\mathrm{NH} 4$ ) from the soil to the root by the AMF. Nitrogen was converted into arginine, then transferred to the plant roots through hypha to external mycelium. Arginine subsequently reorganized into ammonium and then transferred to the plants tissue (Govindarajulu et al., 2005; Jin et al., 2005; Cruz et al., 2007; Tian et al., 2010; Barzin et al., 2014).

\section{$P$ uptake of alfalfa plants}

Effect of AMF and phosphates to the average of $P$ uptake are listed in Table 4 . Results of variance analysis showed that fertilizer $P$ and AMF (single factor or interaction) did not significantly effect on the 
Table 4. Average of $P$ uptake alfalfa plants

\begin{tabular}{ccccc}
\hline \hline \multirow{2}{*}{$\begin{array}{c}\text { AMF } \\
(\mathrm{kg} / \mathrm{ha})\end{array}$} & \multicolumn{3}{c}{ Fertilizer $(\mathrm{kg} / \mathrm{ha})$} & Average \\
\cline { 2 - 4 } & 0 & 60 & 120 & \\
\hline 0.0 & $5.81 \pm 0.13$ & $5.39 \pm 0.78$ & $5.43 \pm 1.31$ & $5.55 \pm 0.23$ \\
0.8 & $4.60 \pm 1.15$ & $4.07 \pm 0.69$ & $4.67 \pm 0.33$ & $4.45 \pm 0.33$ \\
1.6 & $3.95 \pm 1.11$ & $6.11 \pm 1.31$ & $5.66 \pm 0.32$ & $5.24 \pm 1.14$ \\
2.4 & $6.45 \pm 0.72$ & $4.53 \pm 2.26$ & $6.47 \pm 1.11$ & $5.82 \pm 1.11$ \\
Average & $5.20 \pm 1.13$ & $5.03 \pm 0.91$ & $5.56 \pm 0.74$ & \\
\hline
\end{tabular}

P uptake in alfalfa plants. This result was similar with research done by Macolino et al. (2013) found that $P$ fertilizer did not affect the $\mathrm{P}$ content in alfalfa plants. Andrade et al. (2015) reported that in normal soil, AMF has no effect on $P$ content of plants. The results of this study indicate that the possibility of the rate of photosynthesis relatively the same in all treatment, so that the reserve carbohydrates or foods produced from photosynthesis were no different. The study done by Andrade et al. (2015), found that the inoculation AMF has no effect on levels of chlorophyll in the leaves, chlorophyll was one of the elements that are essential to the process of photosynthesis.

Planting medium used in this study contains very low levels of $P$ available, at $4.87 \mathrm{ppm}$, while alfalfa was plants that require $P$ at the boundary sub-optimal. The minimum value of $P$ requirement for alfalfa is 14 ppm (Landon, 2014). Low availability of $P$ in the soil triggered the development of the roots. Hermans et al. (2006) and Karthikeyan et al. (2007) stated that the root adaptation in the soil with low availability of $P$ is increasing the ratio of root/canopy because a large proportion of photosynthesis brought to the roots. Vance et al. (2003), Hermans et al. (2006), Hammond and White, (2008) stated that the soil with $\mathrm{P}$ deficiency would trigger extensive root growth to enlarge the external $P$ acquisition. This condition may generate $P$ uptake in all treatments were not significantly different. It may also be caused by at the 60 days when harvested (post planting) the plant still in young category so that $P$ still be accumulated in the roots and not much transferred to plants leaves. This results similar with research done by Sabia et al. (2015), stated that an application of AMF did does not affect the concentration of $P$ in the plant, probably caused by young barley crop has not been enough time to gather $P$.
Event hough in the statistical tests showed no significant difference, the addition of phosphate fertilizers seem has a positive correlation with $\mathrm{P}$ uptake alfalfa plants. The results of this study showed that the greater additional of $\mathrm{P}$ with followed by the greater number of $P$ uptake in alfalfa plants. Arbuscular mycorrhizal fungi also seem a positive correlation with $P$ uptake. Increasing arbuscular mycorrhizal fungi level followed by increasing the yield alfalfa plant $P$ uptake. Provision of mycorrhizal fungi as much as $2.4 \mathrm{~kg} / \mathrm{ha}$ produced the highest $\mathrm{P}$ uptake compared with other treatments. The results of this study indicate that AMF can improve $P$ uptake in plants alfalfa. The positive correlation between the addition of the $P$ uptake may be caused by AMF able to secrete enzymes that can break the bonds of $P$ with other elements, ultimately can be absorbed by plants. Javot et al. (2007) stated that the AMF could stimulate the secretion of the enzyme phosphatase of plants, so that can release $P$ bound with other elements. A similar finding was found by Cozzolino et al. (2010), Neagoe et al. (2013), and Sarkar et al. (2015), stated that AMF was able to stimulate the phosphatase enzyme that works to increase the availability of $P$ in the soil.

\section{Dry and organic matter in-vitro digestibility}

Effect of AMF and phosphates to the average of dry matter and organic matter in vitro digestibility of alfalfa plants are listed in Table 5.

\section{Dry matter digestibility}

Based on Table 6 shows that the alfalfa plant dry matter digestibility ranges from 70.88 to $83.61 \%$. These results were higher than the dry matter digestibility of alfalfa plant research done by Subantoro et al. (2013) that ranged between 67.93 to 
Table 5. Dry matter in vitro digestibility of alfalfa plants

\begin{tabular}{cllll}
\hline \hline \multirow{2}{*}{$\begin{array}{c}\text { AMF } \\
(\mathrm{kg} / \mathrm{ha})\end{array}$} & \multicolumn{3}{c}{ Fertilizer (kg/ha) } & Average \\
\cline { 2 - 4 } & \multicolumn{1}{c}{60} & \multicolumn{1}{c}{120} & \\
\hline 0.0 & $70.88 \pm 4.16^{\mathrm{a}}$ & $80.24 \pm 0.68^{\mathrm{b}}$ & $72.97 \pm 8.04^{\mathrm{a}}$ & $74.70 \pm 4.91$ \\
0.8 & $77.35 \pm 3.16^{\mathrm{ab}}$ & $76.76 \pm 1.92^{\mathrm{ab}}$ & $83.17 \pm 0.27^{\mathrm{b}}$ & $79.09 \pm 3.54$ \\
1.6 & $72.93 \pm 3.90^{\mathrm{a}}$ & $78.52 \pm 1.89^{\mathrm{ab}}$ & $74.25 \pm 3.51^{\mathrm{a}}$ & $75.23 \pm 2.92$ \\
2.4 & $83.61 \pm 3.98^{\mathrm{b}}$ & $72.43 \pm 2.87^{\mathrm{a}}$ & $78.78 \pm 2.75^{\mathrm{b}}$ & $78.28 \pm 5.61$ \\
Average & $76.19 \pm 5.63$ & $76.99 \pm 3.35$ & $77.29 \pm 4.64$ & \\
\hline
\end{tabular}

${ }_{\mathrm{a}, \mathrm{b}}$ Superscript different on the same row and column shows highly significant $(\mathrm{P}<0.01)$

Table 6. Organic matter in vitro digestibility of alfalfa plants

\begin{tabular}{|c|c|c|c|c|}
\hline \multirow{2}{*}{$\begin{array}{c}\text { AMF } \\
(\mathrm{kg} / \mathrm{ha})\end{array}$} & \multicolumn{3}{|c|}{ Fertilizer (kg/ha) } & \multirow[t]{2}{*}{ Average } \\
\hline & 0 & 60 & 120 & \\
\hline 0.0 & $58.60 \pm 6.73^{a}$ & $68.92 \pm 0.76^{\mathrm{bcd}}$ & $65.21 \pm 2.10^{b c}$ & $64.24 \pm 5.23$ \\
\hline 0.8 & $66.04 \pm 2.85^{b c}$ & $69.54 \pm 1.00^{\mathrm{bcd}}$ & $73.57 \pm 2.94^{d}$ & $69.72 \pm 3.77$ \\
\hline 1.6 & $63.48 \pm 5.42^{a b}$ & $68.29 \pm 0.53^{\mathrm{bcd}}$ & $63.40 \pm 1.25^{\mathrm{ab}}$ & $65.06 \pm 2.80$ \\
\hline 2.4 & $71.55 \pm 2.29^{c d}$ & $64.74 \pm 4.12^{\mathrm{abc}}$ & $67.67 \pm 0.58^{\mathrm{bcd}}$ & $67.99 \pm 3.41$ \\
\hline Average & $64.92 \pm 5.39$ & $67.87 \pm 2.15$ & $67.46 \pm .4 .41$ & \\
\hline
\end{tabular}

$68.40 \%$. The results of this study may be related to the high content of crude protein, so that microbial grew better. In accordance with the opinion of Jems et al. (2014) stated that the high crude protein content could improve rumen microbial growth resulting in increased activity of dry matter digestion.

\section{Organic matter digestibility}

Results of variance analysis showed that the interaction effects were very significant $(P<0.01)$ between the addition of AMF and phosphate fertilizer on organic matter digestibility. Furthermore, results showed that treatment with the addition of $0.8 \mathrm{~kg} / \mathrm{ha}$ AMF followed by the addition of phosphate $120 \mathrm{~kg} / \mathrm{ha}$ showed higher significantly different yield (73.57\%) compared with the treatment without any addition of AMF and phosphate (58.60\%). These results indicated that the interaction between AMF and phosphate to increased the organic matter digestibility.

Organic matter digestibility positively correlated with dry matter digestibility. Dry matter digestibility was significantly different, so was the organic matter digestibility, since dry matter composed of organic and inorganic materials. The organic material is composed of carbohydrates, crude protein, fat, and vitamins. Meanwhile, inorganic (ash) consists of $\mathrm{Ca}, \mathrm{P}$, and another mineral.

\section{Conclusion}

These results indicate that the interaction of AMF and phosphates on the parameters of dry matter and organic matter digestibility, while the other variables were not affected. Addition of AMF ultil $0,8 \mathrm{~kg} / \mathrm{ha}$ with phosphates fertilizer $60 \mathrm{~kg} / \mathrm{ha}$ ables to improve organic matter digestibility.

\section{References}

Andrade, S. A. L. de., A. P. Jr., Domingues and P. Mazzafer. 2015. Photosynthesis is induced in rice plants that associate with arbuscular mycorrhizal fungi and are grown under arsenate and arsenite stress. Chemosphere. 134: 141-9.

AOAC. 2005. Official Method of Analysis of The Association of Official Analytical Chemists. Published by the Association of Official Analytical Chemists, Maryland.

Barzin, H. B., M. F. Rayni, A. Sobhkhizi and M. Noori. 2014. Effect of mycorrhiza fungi on percent of protein, plant height, dry weight, number of panicles in Triticum aestivum. Int. J. Biosci. 5: 111-118.

Baslam, M., M. C. Antolin, Y. Gogorcena, F. Munoz and N. Goicoechea. 2014. 
Changes in alfalfa forage quality and stem carbohydrates induced by arbuscular mycorrhizal fungi (AMF) and elevated atmospheric CO2. Ann. Appl. Biol. 164: 190-199.

Cozzolino, V., M. Pigna, V. Di Meo, A. G. Caporale and A. Violante. 2010. Effects of arbuscularmycorrhizal inoculation and phosphorus supply on the growth of Lactuca sativa $L$. and arsenic and phosphorus availability in an arsenic polluted soil under nonsterile conditions. Appl. Soil Ecol. 45: 262-268.

Cruz, C., H. Egsgaard, C. Trujillo, P. Ambus, N. Requena, M. A. Martins-Loucao and I. Jakobsen. 2007. Enzymatic evidence for the key role of arginine in nitrogen translocation by arbuscular mycorrhizal fungi. Plant Physiol. 144: 782-792.

Daynes, C. N., D. J. Field, J. A. Saleeba, M. A. Cole and P. A. McGee. 2013. Development and stabilisation of soil structure via interactions between organic matter, arbuscular mycorrhizal fungi and plant roots. Soil Biol. Biochem. 57: 683-694.

Fusconi, A. 2014. Regulation of root morphogenesis in arbuscular mycorrhizae: What role do fungal exudates, phosphate, sugars and hormones play in lateral rot formation? Ann. Bot. 113: 19-33.

Garrido, E., A. E. Bennett, J. Fornoni and S. Y. Strauss. 2010. Variation in arbuscular mycorrhizal fungi colonization modifies the expression of tolerance to above-ground defoliation. J. Ecol. 98: 43-49.

Govindarajulu, M., P. E. Pfeffer, H. Jin, J. Abubaker, D. D. Douds, J. W. Allen, H. Bücking, $P$. J. Lammers and $Y$. Shachar-Hill. 2005. Nitrogen transfer in the arbuscular mycorrhizal symbiosis. J. Nature 435: 819-823.

Hammond, J. P. and P. J. White. 2008. Sucrose transport in the phloem: Integrating root responses to phosphorus starvation. J. Experimental Botani 59: 93-109.

Hermans, C., J. P. Hammond, P. J. White and N. Verbruggen. 2006. How do plants respond to nutrient shortage by biomass allocation? J. Trends Plant. Sci. 11: 610-617.
Javot, H., N. Pumplin and M. J. Harrison. 2007. Phosphate in the arbuscular mycorrhizal symbiosis: transport properties and regulatory roles. $\mathrm{J}$. Plant. Cell Environ. 30: 310-322.

Jems, A. M., K. Maaruf, M. R. Waani and C. J. Pontoh. 2014. Pengaruh penggunaan konsentrat dalam pakan rumput benggala (Panicum maximum) terhadap kecernaan bahan kering dan bahan organik pada kambing lokal. J. Zootek. 34: 108-114.

Jin, H., J. Liu, J. Liu and X. W. Huang. 2005. The uptake, metabolism, transport and transfer of nitrogen in an arbuscular mycorrhizal symbiosis. New Phytol. 168: 687-696.

Jones, B. and K. Ljung. 2012. Subterranean space exploration: The development of root system architecture. J. Curr. Opin Plant. Biol. 15: 97-102.

Karthikeyan, A. S., D. K. Varadarajan, A. Jain, M. A. Held, N. C. Carpita and K. G. Raghothama. 2007. Phosphate starvation responses are mediated by sugar signaling in Arabidopsis. $\mathrm{J}$. Planta 225: 907-918.

Landon, J. R. 2014. Booker tropical soil manual: a handbook for soil survey and agricultural land evaluation in the tropics and subtropics. Routledge.

Leifheit, E. F., S. D. Veresoglou, A Lehmann, E. K. Morris and M. C. Rillig. 2013. Multiple factors influence the role of arbuscular mycorrhizal fungi in soil aggregation-a meta-analysis. Plant Soil. 374: 523-537.

Macolino, S., L. M. Lauriault, F. Rimi and U. Ziliotto. 2013. Phosphorus and potassium fertilizer effects on alfalfa and soil in a non-limited soil. Agron J. 105: 1613-1618.

Modupeola, T. O., J. O. Olaniyi, A. M. AbdulRafiu, O. O. Taylor, T. A. Fariyike and T. O. Oyebamiji. 2013. Effect of organic phosphorus fertilizer and plant density on the growth, yield and nutritional value of ginger (Zingiber officinale). Int. J. Agric. Res. 8: 94-100.

Neagoe, A., V. Iordache, H. Bergmann and E. Kothe. 2013. Patterns of effects of arbuscular mycorrhizal fungi on plants grown in contaminated soil. J. Plant. Nutr. Soil. Sci. 176: 273-286.

Parman, S. dan S. Harnina. 2008. Pertumbuhan, kandungan klorofil dan 
serat kasar pada defoliasi pertama alfalfa (Medicago sativa $L$ ) akibat pemupukan mikoriza. Buletin Anatomi dan Fisiologi XVI: 1-6.

Qin, H., K. Lu, P. J. Strong, Q. Xu, Q. Wu, Z. $\mathrm{Xu}$, J. Xu and H. Wang. 2015. Longterm fertilizer application effects on the soil, root arbuscular mycorrhizal fungi and community composition in rotation agriculture. Appl. Soil Ecol. 89: 35-43.

Sabia, E., S. Claps, F. Napolitano, G. Annicchiarico, A. Bruno, R. Francaviglia, L. Sepe and R. Aleandri. 2015. In vivo digestibility of two different forage species inoculated with arbuscular mycorrhiza in Mediterranean red goats. Small Rumin. Res. 123: 83-87.

Sarkar, A., T. Asaeda, Q. Wang and M. H. Rashid. 2015. Arbuscular mycorrhizal influences on growth, nutrient uptake, and use efficiency of Miscanthus sacchariflorus growing on nutrientdeficient river bank soil. Flora Morphol. Distrib. Funct. Ecol. Plants. 212: 46-54.

Setyanti, Y. H., S. Anwar and W. Slamet. 2013. Karakteristik fotosintetik dan serapan fosfor hijauan alfalfa (Medicago sativa) pada tinggi pemotongan dan pemupukan nitrogen yang berbeda. J. Anim. Agric. 2: 8696.

Sirait, J., M. Syawal, dan K. Simanihuruk. 2010. Tanaman alfalfa (Medicago sativa L.) adaptif dataran tinggi iklim basah sebagai sumber pakan: morfologi, produksi, dan palatabilitas. Seminar Nasional Teknologi Peternak dan Veteriner, pp. 519-528.
Subantoro, R., P. Yudono, dan B. Suwignyo. 2013. Pertumbuhan dan hasil tiga varietas alfalfa (Medicago sativa L.) dengan perlakuan tiga macam Rhizobium pada media tanam regosol asal Banguntapan. Jurnal IImu Pertanian 15: 69-84.

Tian, C., B. Kasiborski, R. Koul, P. J. Lammers, H. Bücking and Y. ShacharHill. 2010. Regulation of the nitrogen transfer pathway in the arbuscular mycorrhizal symbiosis: gene characterization and the coordination of expression with nitrogen flux. J. Plant. Physiol. 153: 1175-1187.

Tilley, J. M. A. and R. A. Terry. 1963. A twostage technique for in vitro digestion of forage crops. J. British Grassal. Soc. 28: 104-111.

Vance, C. P., C. Uhde-Stone and D. L. Allan. 2003. Phosphorus acquisition and use: Critical adaptations by plants for securing a nonrenewable resource. New Phytol. 157: 423-447.

Wahyuni, R. D. dan S. N. Kamaliyah. 2012. Studi tentang pola produksi alfalfa tropis (Medicago sativa L.). Jurnal Ilmu-ilmu Peternak 19: 20-27.

Widyati-Slamet, F., Kusmiyati, dan E. D. Purbayanti. 2008. Produksi alfalfa (Medicago sativa) dengan pemupukan fosfat dan interval defoliasi yang berbeda. J. Indon. Trop. Anim. Agri. 33: 158-163.

Xie, X., B. Weng, B. Cai, Y. Dong and C. Yan. 2014. Effects of arbuscular mycorrhizal inoculation and phosphorus supply on the growth and nutrient uptake of Kandelia obovata (Sheue, Liu \& Yong) seedlings in autoclaved soil. J. Appl Soil Ecol. 75: 162-171. 